\title{
HUBUNGAN ASUPAN LEMAK, PERSEN LEMAK TUBUH, SOMATOTYPE DENGAN KELINCAHAN ATLET SEPAKBOLA DIKLAT SALATIGA TRAINING CENTRE (STC)
}

\section{RELATIONSHIP BETWEEN DIETARY FAT INTAKE, BODY FAT PERCENTAGE, SOMATOTYPE WITH AGILITY OF DIKLAT SALATIGA TRAINING CENTER ATHLETES (STC)}

\author{
Rizky Pratama Surya Saputra ${ }^{1}$;Susi Tursilowati ${ }^{2}$;Meirina Dwi Larasati ${ }^{3}$;Sunarto $^{4}$ \\ ${ }^{1}$ Mahasiswa Jurusan Gizi Politeknik Kesehatan Kemenkes Semarang \\ 2,3,4 Dosen Jurusan Gizi Politeknik Kesehatan Kemenkes Semarang
}

\begin{abstract}
Background: Agility is one of the important aspects to achieve maximum achievement. Athletes' agility could be influenced by genetic factors, motivation, training, nutritional status, health status, and somatotype combination. In this study we examine factors that influencing agility are fat intake, body fat percentage, and somatotype.
\end{abstract}

Objective: To determine the relationship between fat intake, body fat percentage, and somatotype with the agility of soccer athletes in the Salatiga Training Center (STC) training.

Method: This study was an observational study with cross sectional design. We used football athletes at the Salatiga Training Center (STC) and included in the inclusion criteria. The Chi Square test was to determine the effect of fat intake, body fat percentage, somatotype on athlete's agility and Logistic Regression test to determine the influences of fat intake, body fat percentage, and somatotype on agility.

Results: There was no relationship between fat intake and the agility of soccer athletes at the Salatiga Training Center (STC) training. There is no relationship between the percentage of body fat with the agility of soccer athletes at the Salatiga Training Center (STC) training. There is no relationship between somatotype and the agility of football athletes at the Salatiga Training Center (STC) training.

Conclusion: There is no relationship between fat intake, body fat percentage, and somatotype with the agility of soccer athletes at the Salatiga Training Center (STC) training.

Keywords: Fat intake, body fat percentage, somatotype, agility.

\section{ABSTRAK}

Latar belakang : Kelincahan merupakan salah satu aspek yang penting untuk dapat meraih prestasi yang maksimal. Kelincahan pemain dapat dipengaruhi oleh kombinasi dari faktor genetik, motivasi, latihan, status gizi, status kesehatan, dan somatotype. Dalam penelitian ini hal hal yang akan diteliti dalam mempengaruhi kelincahan adalah asupan lemak, persen lemak tubuh, dan somatotype.

Tujuan : Untuk mengetahui hubungan antara asupan lemak, persentase lemak tubuh, dan somatotype dengan kelincahan atlet sepak bola diklat Salatiga Training Centre (STC).

Metode : Penelitian ini termasuk penelitian observasional dengan rancangan cross sectional. Sampel yang digunakan yaitu seluruh atlet sepakbola di Salatiga Training Centre (STC) dan termasuk dalam kriteria inklusi. Uji yang digunakan yaitu Uji Chi Square untuk mengetahui pengaruh asupan lemak, persen lemak tubuh, somatotype terhadap kelincahan atlet dan uji Regresi Logistik untuk mengetahui seberapa besar pengaruh asupan lemak, persentase lemak tubuh, dan somatotype terhadap kelincahan.

Hasil : Tidak ada hubungan antara asupan lemak dengan kelincahan atlet sepakbola diklat Salatiga Training Centre (STC). Tidak ada hubungan antara persentase lemak tubuh dengan kelincahan atlet sepakbola diklat Salatiga Training Centre (STC). Tidak ada hubungan antara somatotype dengan kelincahan atlet sepakbola diklat Salatiga Training Centre (STC).

Kesimpulan : Tidak ada hubungan antara asupan lemak, persen lemak tubuh, dan somatotype dengan kelincahan atlet sepakbola diklat Salatiga Training Centre (STC). 
Kata kunci : Asupan lemak, persentase lemak tubuh, somatotype, kelincahan.

\section{PENDAHULUAN}

Dunia olahraga sangat erat kaitannya dengan pencapaian prestasi atlet. ${ }^{1}$ Prestasi olahraga Indonesia mengalami pasang dan surut pada tiga periode SEA Games terakhir, yaitu tahun 2013, 2015, dan 2017. ${ }^{2}$ Indonesia menempati juara ke empat pada tahun 2013, pada tahun 2015 Indonesia menempati peringkat ke lima, dan pada tahun 2017 Indonesia masih tetap pada peringkat kelima- ${ }^{3}$ Terjadinya pasang surut dalam prestasi altet ini dikarenakan kondisi fisik atlet yang tidak prima. Cabang Olahraga yang juga mengalami pasang surut prestasi adalah Sepakbola.

Sepak bola merupakan salah satu olahraga paling populer yang mempunyai banyak penggemar di dunia, termasuk di Indonesia. Sering dijumpai perhatian masyarakat tertuju kearah pertandingan sepak bola baik di layar kaca maupun di lapangan langsung. Sepak bola mempunyai nilai tersendiri di mata penggemarnya, terutama bagi mereka yang mempunyai kemampuan dan kelebihan dalam permainan ini. ${ }^{1}$ Oleh karena itu, prestasi dalam olahraga menjadi hal yang sangat penting karena menjadi sorotan publik, dan seharusnya terus dilakukan upaya untuk peningkatan prestasi di bidang sepak bola. Salah satu faktor internal yang dapat mempengaruhi prestasi dalam olahraga sepakbola adalah kelincahan pemain.

Kelincahan pemain menjadi peran penting dalam pencapaian prestasi sepak bola. Kelincahan dibutuhkan oleh seseorang pemain sepak bola dalam menghadapi situasi tertentu dan kondisi pertandingan yang menuntut unsure kelincahan dalam bergerak untuk menguasai bola maupun dalam bertahan untuk menghindari benturan yang mungkin terjadi. Kecepatan dan kelincahan dapat dilatih secara bersama-sama, baik dengan bola maupun tanpa bola. Bagi seorang pemain sepak bola situasi yang berbeda-beda selalu dihadapi dalam setiap pertandingan, juga seorang pemain sepak bola menghendaki gerakan yang indah dan cepat sering dilakukan unsur kelincahan. ${ }^{3}$ Kelincahan pemain dapat dipengaruhi oleh kombinasi dari faktor genetik, motivasi, latihan, gizi, status kesehatan, dan somatotype. ${ }^{2}$ Kelincahan ini berkaitan erat antara kecepatan dan kelenturan. Tanpa kedua unsure tersebut, seseorang tidak dapat bergerak dengan lincah. Selain itu, faktor keseimbangan sangat berpengaruh terhadap kemampuan kelincahan seseorang. ${ }^{4}$ Zat Gizi yang dominan dalam mempengaruhi kelincahan adalah lemak, karena lemak dapat tertimbun dengan mudah, serta timbunan lemak tubuh akan meningkatkan berat badan atlet dan kondisi tersebut yang mempengaruhi perawakan tubuh manusia (somatotype). ${ }^{5}$ Dalam penelitian yudiana menyebutkan bahwa terdapat korelasi dan pengaruh energy dan lemak terhadap nilai kelincahan. ${ }^{6}$

Semakin tinggi persentase lemak tubuh dan semakin endomorphy tubuh seorang atlet, akan menyebabkan percepatan pergerakan seseorang berkurang. Gerakan fisik dalam olahraga dikaitkan dengan skill related fitness atau kebugaran berkaitan dengan keterampilan. ${ }^{2}$ Salatiga Training Centre (STC) merupakan salah satu training center yang ada di Salatiga yang melakukan latihan rutin 2 kali dalam sehari. Salatiga Training Centre (STC) di dalam perekrutannya belum mensyaratkan mengenai bentuk tubuh / somatotype. Salatiga Training Centre (STC) pada tahun 2017 hanya meraih 2 piala dari kompetisi lokal, kedua juara tersebut adalah juara 2 dan juara 3. Salatiga Training Centre (STC) belum pernah menjuarai kompetisi nasional. Berdasarkan uraian tersebut, penulis berminat untuk meneliti hubungan asupan lemak, persen lemak tubuh, somatotype dengan kelincahan atlet sepakbola di Diklat Salatiga Training Centre (STC).

Tujuan dari penelitian ini untuk mengetahui hubungan antara asupan lemak, persentase lemak tubuh, dan somatotype dengan kelincahan atlet sepak bola diklat Salatiga Training Centre (STC).

\section{METODE}

Penelitian ini merupakan jenis penelitian observasional dengan rancangan cross sectional. Lokasi penelitian dilakukan di Diklat Salatiga Training Centre (STC). Sampel dalam penelitian ini meliputi 34 orang yang berusia 15 - 18 tahun. Semua sampel diwawancarai untuk mendapatkan data asupan lemak, setelah itu dilakukan pengukuran tinggi badan, berat badan dan persen lemak tubuh untuk mengetahui status gizi serta presentase lemak. Selanjutnya peneliti melakukan pengukuran somatotype pada sampel penelitian serta melakukan pengukuran kelincahan(agility).

Variabel penelitian meliputi variabel berpengaruh (independen) yaitu asupan lemak, presen lemak tubuh, dan somatotype dan variabel yang dipengaruhi (dependen) yaitu kelincahan (agility). Instrumen yang digunakan terdiri dari formulir informed concern, formulir penilaian konsumsi lemak dengan metodeSQ -FFQ (Semi Kuantitatif Food Frequency), formulir persen lemak tubuh dan formulir somatotype, formulir penilaian 
kelincahan atlet dengan metode Illinois agility test, timbangan berat badan, microtoise, kuesioner FFQ, Bioelectrical Impedance Analysis (BIA), skinfold caliper, jangka sorong,stopwatch, dan metlin.

Penelitian ini menggunakan 3 analisis yaitu analisis uni variat, bivariat dan multivariat. Analisis univariat dilakukan untuk mendeskripsikan asupan lemak, persen massa lemak tubuh, somatotype, dan kelincahan. Analisis bivariat untuk melihat pengaruh kelincahan (agility) dengan asupan lemak, persen massa lemak tubuh, dan somatotype dengan menggunakan Uji Fisher's Exact. Sedangkan untuk analisis multivariat menggunakan Uji Regresi Logistik untuk mengetahui seberapa besar pengaruh asupan lemak, persentase lemak tubuh, dan somatotype dengan kelincahan (agility).

\section{HASIL PENELITIAN}

\section{A. Gambaran Umum Lokasi Penelitian}

Diklat Salatiga Training Centre (STC) merupakan sekolah pembibitan olahraga lokal, yang digunakan untuk mencari dan membina bakat olahraga sepakbola pada usia sekolah. Diklat Salatiga Training Centre (STC) merupakan wadah pembinaan olahraga pelajar yang didirikan oleh Bapak Nur Khamid yang bertempat di Salatiga.

Diklat Salatiga Training Centre (STC) hanya fokus membina satu cabang olahraga yaitu sepakbola. STC beralamatkan di Jl. Singoprakoso No. 13 RT 04 / RW 02 Sidorejo Kidul, Tingkir, Salatiga, Jawa Tengah 50741. Atlet sepakbola STC merupakan siswa laki - laki yang bersedia mendaftar dan tinggal di mess STC. Atlet STC datang dari berbagai wilayah di pulau Jawa dan pulau Kalimantan.

\section{B. Karakteristik Sampel}

Tabel 1. Karakterikstik Sampel Atlet Sepak bola Salatiga Training Centre (STC)

\begin{tabular}{|c|c|c|c|c|c|c|c|c|c|}
\hline & & \multicolumn{2}{|c|}{ Iumlah } & \multicolumn{2}{|c|}{ Lincah } & \multicolumn{2}{|c|}{ TidakLincah } & \multicolumn{2}{|c|}{ Total } \\
\hline & & $\mathrm{N}$ & $\%$ & $\mathrm{n}$ & $\%$ & $\mathrm{n}$ & $\%$ & $\mathrm{n}$ & $\%$ \\
\hline \multirow{4}{*}{ Umur } & 15 & 6 & 17,6 & 9 & 26,5 & 7 & 20,6 & 16 & 47,1 \\
\hline & 16 & 18 & 52,9 & 2 & 5,9 & 8 & 23,5 & 10 & 29,4 \\
\hline & 17 & 7 & 20,6 & 0 & 0,0 & 5 & 14,7 & 5 & 14,7 \\
\hline & 18 & 3 & 8,8 & 1 & 2,9 & 2 & 5,9 & 3 & 8,8 \\
\hline \multirow{3}{*}{ IMT } & Kurus & 9 & 26,5 & 6 & 17,6 & 3 & 8,8 & 9 & 26,5 \\
\hline & Normal & 20 & 58,8 & 6 & 17,6 & 14 & 41,2 & 20 & 58,8 \\
\hline & Gemuk & 5 & 14,7 & 0 & 0,0 & 5 & 14,7 & 5 & 14,7 \\
\hline
\end{tabular}

Dalam tabel tersebut dapat dijelaskan bahwa sebagian besar sampel berusia 16 tahun dengan jumlah presentase $52,9 \%$. Sampel yang berusia 17 dan 18 tahun sedikit dikarenakan pada saat pengambilan data, sudah dalam masa liburan dan kelulusan siswa SMA, dan sampel dengan usia 17 dan 18 tahun rata - rata sudah lulus dan sudah pulang ke rumahnya dan sudah tidak berada di mess Salatiga Training Centre (STC).

Data karakteristik selanjutnya adalah distribusi kategori IMT, sebagian besar sampel memiliki IMT yang normal dengan jumlah sampel sebanyak 20 dan dengan presentase $58,8 \%$. Hal ini menunjukkan bahwa sebagian besar atlet yang ada tidak memiliki masalah dengan IMT nya dikarenakan ssebagian besar sampel memiliki IMT yang normal.

\section{Analisis Univariat}

\section{Asupan Lemak}

Tabel 2.Distribusi Asupan Lemak Atlet Sepak bola Salatiga Training Centre (STC)

\begin{tabular}{lccc}
\hline \multirow{2}{*}{ Asupan Lemak } & \multicolumn{2}{c}{ Jumlah } \\
\cline { 2 - 4 } & & $\mathbf{n}$ & $\%$ \\
\hline Baik & 14 & 41.2 \\
Kurang & 20 & 58.8 \\
\hline \multicolumn{2}{c}{ Total } & 34 & 100.0 \\
\hline
\end{tabular}

Berdasarkan table diatas dapat diketahui bahwa frekuensi asupan lemak atlet yang baik sebanyak 14 atlet dengan presentase $41,2 \%$, dan frekuensi asupan lemak yang kurang sebanyak 20 atlet dengan presentase $58,8 \%$. Asupan lemak rata - rata atlet sepakbola Salatiga Training Centre (STC) adalah sebesar 74,26\% dari AKG, asupan lemak minimum sebesar $53 \%$ dan asupan lemak maksimum sebesar $95 \%$. Data tersebut menunjukkan bahwa kebanyakan atlet mengkonsumsi lemak tidak sesuai dengan kebutuhan tubuhnya masing masing. Hal ini dikarenakan atlet belum mendapatkan pengetahuan mengenai asupan lemak yang sesuai dengan kebutuhan tubuhnya masing masing, serta atlet dapat dengan leluasa membeli makanan selain makanan yang diberikan dari pihak Salatiga Training Centre (STC).

\section{Persen Lemak Tubuh}

Table 3. Distribusi Persen Lemak Tubuh Atlet Sepak bola Salatiga Training Centre (STC) 


\begin{tabular}{lcc}
\hline \multirow{2}{*}{ Persen Lemak Tubuh } & \multicolumn{2}{c}{ Jumlah } \\
\cline { 2 - 3 } \multicolumn{1}{c}{ N } & $\%$ \\
\hline Proporsional & 26 & 76.5 \\
Tidak Proporsional & 8 & 23.5 \\
\hline \multicolumn{1}{c}{ Total } & 34 & 100.0 \\
\hline
\end{tabular}

Berdasarkan data karakteristik subjek menurut persen lemak tubuh menunjukkan bahwa sebanyak 26 atlet (76,5\%). Persen lemak tubuh atlet memiliki rata - rata sebesar $12,82 \%$. Persen lemak tubuh minimal pada sampel adalah sebesar $7 \%$, dan persen lemak tubuh maksimal pada sampel sebesar 18,6\%. Data tersebut menunjukkan bahwa sebagian besar atlet di Salatiga Training Centre (STC) memiliki persen lemak tubuh yang proporsional.

\section{Somatotype}

Tabel 4. Distribusi Somatotype Atlet Sepak bola Salatiga Training Centre (STC)

\begin{tabular}{lccc}
\hline \multirow{2}{*}{ Somatotype } & \multicolumn{2}{c}{ Jumlah } \\
\cline { 2 - 3 } & $\mathbf{n}$ & $\%$ \\
\hline Endomorph & 15 & 44.1 \\
Ectomorph & 19 & 55.9 \\
\hline \multicolumn{1}{c}{ Total } & 34 & 100.0 \\
\hline
\end{tabular}

Tabel diatas menunjukkan bahwa frekuensi somatotype type endomorph sebanyak 15 atlet dengan presentase $44,1 \%$, dan frekuensi somatotype type ectomorph sebanyak 19 atlet dengan presentase 55,9\%. Data tersebut menunjukkan bahwa type tubuh atlet sepakbola Salatiga Training Centre (STC) hampir seimbang antara atlet dengan type tubuh endomorph dan atlet dengan type tubuh ectomorph. Hal ini dikarenakan tidak ada seleksi pada saat awal penerimaan bibit atlet baru yang ingin berlatih di diklat Salatiga Training Centre (STC).

\section{Kelincahan}

Tabel 5.Distribusi Tingkat Kelincahan Atlet Sepak bola Salatiga Training Centre (STC)

\begin{tabular}{lccc}
\hline \multirow{2}{*}{ Kelincahan } & \multicolumn{2}{c}{ Jumlah } \\
\cline { 3 - 4 } & & $\mathbf{n}$ & $\%$ \\
\hline Lincah & 12 & 35.3 \\
Tidak Lincah & 22 & 64.7 \\
\hline \multicolumn{2}{c}{ Total } & 34 & 100.0 \\
\hline
\end{tabular}

Tabel diatas menunjukkan bahwa frekuensi atlet yang dikatakan lincah sebanyak 12 dengan frekuensi 35,3\% dan atlet yang dikatakan tidak lincah sebanyak 22 dengan frekuensi 64,7\%. Data tersebut menunjukkan bahwa masih banyak atlet yang dikatakan tidak lincah.

\section{Analisis Bivariat}

1. Hubungan Asupan Lemak dengan Kelincahan

Tabel 6. Distribusi Hubungan Asupan Lemak dengan Kelincahan Atlet Sepakbola Salatiga Training Centre (STC) Tahun 2018

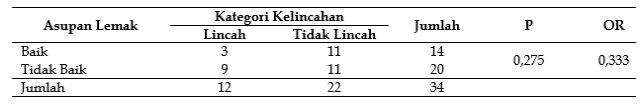

Tabel diatas menunjukkan bahwa antara kelompok atlet dengan asupan lemak yang baik dan kelompok atlet dengan asupan lemak yang tidak baik memiliki kesamaan jumlah atlet yang tidak lincah, yaitusebesar 11 sampel.Hasiluji statistik menggunakan uji Fisher's Exact antara asupan lemak dengan kelincahan menghasilkan $p=0,275$ (nilai $p>0,05$ ) yang berarti Ha ditolak dan Ho diterima. Dapat disimpulkan bahwa tidak terdapat hubungan antara asupan lemak dengan kelincahan pada atlet sepakbola Salatiga Training Centre (STC). Hasil ini sejalan dengan penelitian Hosianna (2017) yang menyatakan bahwa tidak terdapat hubungan antara asupanlemak terhadap kelincahan. $^{7}$

2. Hubungan Persen Lemak Tubuh dengan Kelincahan

Tabel 7. Distribusi Hubungan Persen Lemak Tubuh dengan Kelincahan Atlet Sepakbola Salatiga Training Centre (STC) Tahun 2018

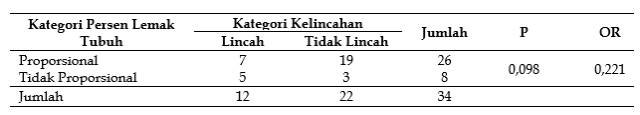

Tabel diatas menunjukkan bahwa antara kelompok atlet dengan persen lemak tubuh proporsional lebih banyak daripada kelompok atlet dengan persen lemak tidak proporsional. Walaupun kelompok atlet dengan persen lemak proporsional lebih banyak sebesar 26 sampel, tetapi dalam kelompok tersebut sebanyak 19 sampel tergolong kedalam kategori tidak lincah. 
Berdasarkan hasil uji statistik menggunakan uji Fisher's Exact antara persen lemak tubuh dengan kelincahan menghasilkan $p=0,066$. Dapat disimpulkan bahwa tidak terdapat hubungan antara persen lemak tubuh dengan kelincahan pada atlet sepakbola Salatiga Training Centre (STC). Hal ini sejalan dengan penelitian Narruti (2012) yang menyatakan bahwa tidak ada hubungan antara persentase lemak tubuh dengan kelincahan. ${ }^{5}$

\section{Hubungan Somatotype dengan Kelincahan.}

Tabel 8. Distribusi Hubungan Somatotype dengan Kelincahan Atlet Sepakbola Salatiga Training Centre (STC) Tahun 2018

\begin{tabular}{|c|c|c|c|c|c|}
\hline Kategori Somatotype & & elincahan & Jumlah & $P$ & OR \\
\hline Endomorph & Lincah & Tidak Lincah & J & & \\
\hline $\begin{array}{l}\text { Lnomnorph } \\
\text { Ectorph }\end{array}$ & 9 & $\begin{array}{l}12 \\
10\end{array}$ & $\begin{array}{l}190 \\
29\end{array}$ & 0,097 & 0,278 \\
\hline Jumlah & 12 & 22 & 34 & & \\
\hline
\end{tabular}

Tabel diatas menunjukkan bahwa antara kelompok atlet dengan somatotype ectomorph lebih banyak daripada kelompok atlet dengan somatotype endomorph. Kedua kelompok atlet tesebut sama - sama memiliki jumlah samapel yang tidak lincah lebih banyak. Kelompok atlet Endomorph dengan jumlak 15 terdapat sampel dalam kategori tidak lincah sebanyak 12. Kelompok atlet ectomorph dengan jumlah 29 terdapat sampel dalam kategori yang tidak lincah sebanyak 10.

Hasil uji statistik menggunakan uji Chi-Square antara somatotype dengan kelincahan menghasilkan $p=0,097$. Dapat disimpulkan bahwa tidak terdapat hubungan antara somatotype dengan kelincahan pada atlet sepakbola Salatiga Training Centre (STC). Hasil ini sejalan dengan penelitian Qurun (2016) yang menyatakan bahwa tidak terdapat hubungan yang signifikan antara somatotype dengan kelincahan. ${ }^{8}$

\section{E. Analisis Multivariat}

Tabel 9. Hasil Analisis Uji Regresi Logistik Atlet Sepakbola Salatiga Training Centre (STC) Tahun 2018

\begin{tabular}{llcccccc}
\hline & & B & S.E. & Wald & df & Sig. & Exp(B) \\
\hline \multirow{5}{*}{ Step 1. } & Kat Prsn Lmk & .929 & 1.015 & .839 & 1 & .360 & 2.533 \\
& Somatotype & .710 & .940 & .571 & 1 & .450 & 2.034 \\
& Kat As Lmk & .403 & .941 & .183 & 1 & .669 & 1.496 \\
& Constant & -.511 & .730 & .489 & 1 & .484 & .600 \\
& Kat Prsn Lmk & 1.070 & .962 & 1.237 & 1 & .266 & 2.917 \\
Step 2a & Somatotype & .827 & .900 & .844 & 1 & .358 & 2.286 \\
& Constant & -.511 & .730 & .489 & 1 & .484 & .600 \\
& Kat Prsn Lmk & 1.509 & .854 & 3.126 & 1 & .077 & 4.524 \\
Step 3* & Constant & -.511 & .730 & .489 & 1 & .484 & .600 \\
& & & & & & &
\end{tabular}

Analisis multivariat menggunakan uji regresi logistik dilakukan apabila nilaip value $<0,25$, jika $p$ value $>0,25$ dan variabel tersebut secara substansi penting, maka variabel tersebut dapat masuk kedalam analisis multivariat. ${ }^{9}$ Hasil analisis Fisher's Exact antara asupan lemak dengan kelincahan menghasilkan nilai $p=0,275$, antara persen lemak dengan kelincahan menghasilkan nilai $\mathrm{p}=0,098$, dan somatotype dengan kelincahan menghasilkan nilai $p=0,097$. Dari hasil analisis menggunakan uji Fisher's Exact tersebut, hanya persen lemak dan somatotype yang memenuhi syarat untuk dilakukan uji regresi logistik, tetapi asupan lemak juga dimasukkan kedalam analisis karena variabel tersebut penting secara substansi.

Hasil uji statistik menggunakan uji regresi logistik menghasilkan data seperti tabel 9 diatas. Pada step pertama dapat diambil kesimpulan bahwapersen lemak tubuh proporsional cenderung akan menyebabkan seorang atlet menjadi lincah sebanyak 2,53 kalinya jika dibandingkan atlet yang memiliki persen lemak tidak proporsional, dan somatotype ectomorph cenderung akan menyebabkan seorang atlet menjadi lincah sebanyak 2,03 kalinya jika dibandingkan atlet yang memiliki somatotype endomorph. Sedangkan asupan lemak yang baik cenderung akan menyebabkan seorang atlet menjadi lincah sebanyak 1,49 kalinya jika dibandingkan atlet yang memiliki asupan lemak yang tidak baik.

Dikarenakan pada step pertama persen lemak tubuh dan somatotype menyumbang pengaruh yang lebih besar daripada asupan lemak, maka pada step kedua asupan lemak dieliminasi dan dilihat kecenderungan pengaruh persen lemak tubuh dan somatotype terhadap kelincahan pada atlet tersebut. Kesimpulan yang dapat diambil pada step kedua adalah persen lemak tubuh proporsional pada seorang 
atlet dapat meningkatkan kelincahan sebesar 2,91 kali dibandingkan dengan atlet yang mempunyai persen lemak tubuh tidak proporsional dan somatotype ectomorph cenderung akan menyebabkan seorang atlet menjadi lincah sebanyak 2,28 kalinya jika dibandingkan atlet yang memiliki somatotype endomorph.

Karena pada step kedua persen lemak tubuh menyumbang pengaruh yang lebih besar dibandingkan dengan somatotype, maka somatotype dieliminasi pada step ketiga dan hanya menganalisis kecenderungan persen lemak tubuh dengan kelincahan. Hasil yang dapat diambil pada step ketiga adalah persen lemak tubuh proporsional pada seorang atlet dapat meningkatkan kelincahan sebesar 4,52 kali dibandingkan dengan atlet yang mempunyai persen lemak tubuh tidak proporsional.

\section{KESIMPULAN}

Berdasarkan analisis bivariat diperoleh hasil tidak ada hubungan antara asupan lemak dengan kelincahan atlet sepak bola diklat Salatiga Training Centre (STC), tidak ada hubungan antara persentase lemak tubuh dengan kelincahan atlet sepakbola diklat Salatiga Training Centre (STC), dan tidak ada hubungan antara somatotype dengan kelincahan atlet sepakbola diklat Salatiga Training Centre (STC). Sedangkan berdasarkan analisis multivariat diperleh hasil persen lemak tubuhproporsional pada seorang atlet dapat meningkatkan kelincahan sebesar 4,52 kali disbandingkan dengan atlet yang mempunyai persen lemak tubuh tidak proporsional.

\section{SARAN}

Bagi Diklat Salatiga Training Centre (STC)diharapkan melakukan edukasi mengenai asupan makanan yang baik dan sehat bagi atlet ketika diluar mess STC dan bagi atlet sepakbola Salatiga Training Centre (STC)diharapkan agar lebih memperhatikan pola makan dan asupan makronutrien, agar asupan makan terutama asupan makronutrien yang cepat menjadi timbunan lemak menjadi lebih baik dan tidak menjadikan suatu masalah kesehatan.

\section{DAFTAR PUSTAKA}

1. Pratiwi D. Hubungan Somatotype dan Performa Fisik pada Atlet Sepak Bola Tim Nasional (Timnas) U-19 dan Atlet Sepak Bola Mahasiswa. 2013;1-9.
2. Kris Fathoni. Hasil-Hasil Timnas Indonesia di Cabang Sepakbola SEA Games. Detik Sport [Internet]. 2017 Aug 15; Available from: https://sport.detik.com/sepakbola/ligaindonesia/d-3600077/hasil-hasil-timnasindonesia-di-cabang-sepakbola-sea-games

3. Susanto. Prestasi Olahraga Indonesia Sentuh Level Terendah di Asia Tenggara. Sindo News [Internet]. 2017 Aug 30; Available from: https://sports.sindonews.com/read/1235271 /51/prestasi-olahraga-indonesia-sentuhlevel-terendah-di-asia-tenggara-1504085022

4. Budianto A. Hubungan Antara Kecepatan dan Kelincahan Terhadap Keterampilan Bermain Sepakbola Siswa Usia 14 - 15 Tahun di Sekolah Sepakbola Baturetno Bantul. 2012;

5. Narruti NH. Hubungan Asupan Lemak, Persentase Lemak Tubuh, somatotype dengan Kelincahan Atlet Pencak Silat Kategori Latih Tanding Pelatihan Daerah (PELATDA) Daerah Istimewa Yogyakarta. 2012;(February):1-6.

6. Yudiana $\mathrm{Y}$, Subardjah $\mathrm{H}$, Juliantine T. Latihan Fisik. Fpok-Upi. 2007;(1):2.

7. Hosianna DC, Hapsari M. Hubungan Asupan Zat Gizi Makro dan Somatotype terhadap Kelincahan Pemain Sepakbola Unit Kegiatan Mahasiswa (UKM) di Daerah Istimewa Yogyakarta. 2017;2-3.

8. Qurun DK. Hubungan Somatotype dengan Kelincahan Atlet Sepak Takraw UPT SMA Negeri Olahraga Jawa Timur. Dep Antropol Fak IImu Sos dan Ilmu Polit Univ Airlangga, Surabaya. 2016;5(2):232-8.

9. Dahlan S. Statistik untuk Kedokteran dan Kesehatan: Deskriptif, Bivariat, dan Multivariat. Epidemiologi Indonesia; 2015.

10. Sumiyarsono D. Keterampilan Bola Basket. In Yogyakarta; 2002.

11. Sajoto M. Peningkatan dan Pembinaan Kondisi Fisik dalam Olah Raga. In Jakarta; 1988.

12. Ismaryati. Tes Dan Pengukuran Olahraga. In: 2nd ed. Surakarta: LPP UNS dan UNS Press; 2008.

13. Mutohir TC, Maksum A. Sport Development Index. state Univ surabaya. 2007;

14. Purwanto J. Hoki. In Yogyakarta: FIK UNY; 2004.

15. Depdiknas. Permainan Berhitung di Taman Kanak-Kanak. In Jakarta: Depdiknas; 2000.

16. Faruq MM. Meningkatkan Kebugaran Jasmani Melalui Permainan dan Olahraga Bola Voli. In Jakarta: PT. Gramedia Widiasarana Indonesia; 2009. p. 15.

17. Getchell B. Physical Fitness: A Way of Life. Second Edition. New Jersey; 1979. 352 p. 
18. Davis B, Bull R, Roscoe J, Roscoe D. Physical Education \& the Study of Sport. 4th ed. United Kingdom: C.V. Mosby; 2000.

19. Supariasa IDN. Penilaian Status Gizi. Jakarta: Penerbit Buku kedokterasn EGC; 2002.
20. Irianto A. Statistika Konsep Dasar dan Aplikasinya. Jakarta: Kencana; 2007. 